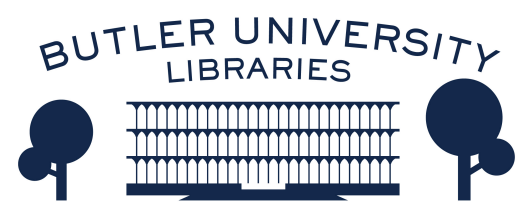

Journal of Hindu-Christian Studies

\title{
Book Review: The Continuing Quest: Carrying Forward the Contemplative and Prophetic Vision of Bede Griffiths
}

\author{
Michael McLaughlin \\ Old Dominion University
}

Follow this and additional works at: https://digitalcommons.butler.edu/jhcs

Part of the Christianity Commons, Hindu Studies Commons, and the Religious Thought, Theology and Philosophy of Religion Commons

\section{Recommended Citation}

McLaughlin, Michael (2017) "Book Review: The Continuing Quest: Carrying Forward the Contemplative and Prophetic Vision of Bede Griffiths," Journal of Hindu-Christian Studies: Vol. 30, Article 26.

Available at: https://doi.org/10.7825/2164-6279.1678

The Journal of Hindu-Christian Studies is a publication of the Society for Hindu-Christian Studies. The digital version is made available by Digital Commons @ Butler University. For questions about the Journal or the Society, please contact cbauman@butler.edu. For more information about Digital Commons @ Butler University, please contact digitalscholarship@butler.edu. 
appeals to secularism or the Rg Vega's aphorism proclaiming the oneness and many names for truth, contemporary dancers have also creatively evoked bhakti rasa as a human connection that expands its devotional, cultural, and ethical meanings into an imperative for cooperation and dialogue.

Throughout this text, Zubko demonstrates her mastery of texts, theory, and technical detail. Her overviews of the construction of both rasa and bharata natyam are exemplary. Only in the conclusion of the fourth movement did I find myself hoping for more. Unlike each of the first three sections, which close their argument by engaging relevant theory, the fourth misses an opportunity to connect with contemporary conversations on religious pluralism and dialogue. The conclusion helpfully addresses how exclusivity can be embedded in tolerance; and it nicely ties this theme back to the question of which types of identity are permitted in bharata natyam. Because themes of exclusion, inclusion, pluralism, and identity are central to theologies of religion, this reader is curious about how the cases discussed here could amplify those conversations.

Michelle Voss Roberts

Wake Forest University School of Divinity

\section{The Continuing Quest: Carrying Forward the Contemplative and Prophetic Vision of Bede Griffiths. Edited by Thomas Matus and Joseph Wong. Editions of Sankt Ottilien, Germany, 2016, 304 pages.}

THIS volume is a study of the theologian Bede Griffiths (1906-1993), a monk who went to India and immersed himself in the Hindu tradition of spirituality and created his own experiencecentered version of Advaita Vedanta. It originated in a 2006 conference of the Camaldolese Institute for East-West dialogue at Big Sur, California. Griffiths was one of the first Christian monastics to explore Hinduism in depth. It features articles by specialists on Hinduism and on Christian monastic spirituality, a number of whom would consider themselves to be followers of the contemplative spiritual path.

At the start of the book, there is a good overview of the volume which has been provided by the two editors and which gives some good context. The first article by comparative theologian Francis Clooney is a critical analysis of Vedanta and Christian Faith, one of Griffiths' major works. Clooney criticizes Griffiths, not for his spiritual path, but for his version of Advaita Vedanta which Clooney, no doubt rightly, considers weak in its attention to the technical commentaries on Advaita and their specific questions and vocabulary. The commentarial tradition is an area in which Clooney has worked extensively. He argues that the thought of a figure like Sankara can only be recovered in this way, since Sankara says almost nothing about his own spiritual experiences.

Brad Malkovsky's article stresses the significant differences in the theology of revelation between Hinduism and Christianity. In particular, the Christian understanding of divine revelation as something which 
progressively unfolds in history as well as the Christian understanding of eschatology are aspects which do not have parallels in Hinduism. He criticizes Griffiths for assuming an almost monolithic Hindu understanding of certain doctrines such as the doctrine of cyclical time, seen therefore as "purposeless" while at the same time approving of the author's desire not to negotiate away the unique Christian understanding of the incarnation as a once for all union of the divine with the human. Malkovsky's analysis points out that the cosmic revelation of the divine as present in all creation is clarified in Christianity by an additional historical revelation which "throws new light on both the created order and on the nature of the divine and the divine will for the world." This is a very important point. For Christians, this means that the Divine itself has a purpose or goal unlike the Divine in most Asian systems. Malkovsky adds that Griffiths uses the term "revelation" in an imprecise manner where it sometimes means only general mystical experience and intuitive wisdom. (A reference here would be the Vatican II document Dei Verbum where both the words and deeds of Jesus are revelation.)

In a very detailed article, which cannot be easily summarized here, Joseph $\mathrm{H}$. Wong suggests that the Advaita of Griffiths might be seen as another form of qualified Advaita, one that has a more adequate, non-pantheistic, understanding of creation. Wong suggests that this position might be intermediate between Sankara and Madhva. Such a stance arises because Christ as the Word of God has united himself with all of human nature in a certain mysterious way, and moreover, the entire cosmos has in some way become the extended body of Christ through the incarnation. (He does not try to deal with the nature of the church itself, at once both holy and sinful). There is a unity in distinction between God and the world. The spirit of the glorified Christ (I Cor.15:44-45) has taken possession of matter and of the entire creation and transformed it in a way different than what is seen in Sankara where creation is God's lila or play. For Griffith's Christian Advaita, the unity in distinction at the level of the individual person is modeled as equal to Jesus' Abba experience in the Spirit, a Spirit of love and relationship.

The article by Joseph Prabhu juxtaposes the thought of Bede Griffith with that of Raimundo Panikkar who is more highly philosophical but whose immersion in Hinduism makes for a fruitful comparison. Put very briefly, Panikkar's ontology is a Buddhist inspired one in which he stresses the "interdependence and interrelatedness of all things and the co-arising of all processes" where the One "emerges in and through differences" and is "radically relational". In Panikkar's Trinitarian theology, unlike Bede's, only the Son is strictly speaking a person, the Father and the Spirit are not; one can have a personal relationship only with the Son. In Griffiths' thought, the Trinity is an interpersonal and real communion in love. In Panikkar, if I understand Prabhu correctly, there is more a sense of the self being completely merged into the divine so that it " loses [even] the memory of its own existence". It is a jnana yoga rather than the more interpersonal bhakti yoga of Bede Griffiths.

Robert Hale's article researches prophetic dimension of Bede's thought as well as his understanding of sexuality. He details Bede's education and things that influenced him as a university student coming from a poor family. He notes that Bede rejected any spirituality that 
tried to ignore the body and its natural desires, which must be integrated into the whole self. Hale supplies valuable insights about Bede's rejection of a legalistic, moralistic church. Bede did not neglect social justice but created projects at his ashram Shantivanam such as a dispensary, spinning looms and a nursery school which helped to empower the poor of the area. He also had many ideas on the reform of the Catholic Church to counteract what he saw as an excessively hierarchical structure and wrote frequently to the Tablet on this subject. He criticized the church teaching on homosexual persons. He was strongly in favor of ecumenism. Later in life, he had many women who were disciples and friends. He had long rejected the male-only concept of the Catholic priesthood. This article does an excellent job of presenting the human side of Griffiths and his life projects. His prophetic stance also challenges Indian society for its casteism and patriarchy.

Because of limitations of space, I will not discuss the contributions of Beatrice Bruteau on consciousness, of Michael von Brück on religious language, of Sr. Donald Corcoran on the Holy Spirit or the interesting panel discussion. The briefer pieces at the end of the volume represent personal reflections by individuals who knew Bede Griffiths and comment on his role as a guru and mentor to many.

This book will be useful for those trying to situate Bede Griffiths with respect to the Hindu tradition. One useful comparison is to the experiential approach to Vedanta of Vivekananda. This collection clarifies many issues about the appropriation of Hinduism by individuals seeking to participate in what now might be called multiple religious belonging. Besides navigating the many theological differences on the meaning of revelation, incarnation, eschatology and the Trinity mentioned above, it seems clear that, like Griffiths, each person who seeks to do this will have to find his or her own path through the many living forms of Hindu spirituality and the many varieties of religious experience. There is a valid question of how to evaluate new versions of Hinduism that are original rather than based on a deep reference to the commentaries of Sankara, Ramanuja and others. Hinduism itself is evolving especially in its manifestations outside of the Indian subcontinent. Unfortunately, in India today there are those fundamentalists who oppose other religions and call for a pure Hindu nation wherein a Griffiths might be suspect as might a comparative approach from Islam. Many seekers who love what they find in the Hindu classics will no doubt want to sit at the feet of an authentic guru to get some help in understanding their deeper selves and their experiences of meditation. It is clear from the testimonies of this volume that Griffiths was a compassionate and caring friend to many who sought his advice and that there is no better way to truly teach than by examples like his. The participants in this volume are to be commended for making a significant effort at learning from and extending the legacy of Bede Griffiths.

Michael McLaughlin

old Dominion University 